\title{
PENGEMBANGAN BAHAN AJAR SEJARAH ASIA TIMUR BERBASIS AUGMENTED REALITY DALAM MENINGKATKAN KETERAMPILAN BERPIKIR KREATIF
}

Mhd Ihsan Syahaf Nasution, Fakultas IImu Sosial Universitas Negeri Medan, ihsansyahafnasution@gmail.com

\begin{abstract}
ABSTRAK.
Penelitian ini dilandasai dari kurangnya keterampilan berpikir kreatif diantara mahasiswa pada mata kuliah Sejarah Asia Timur. Mahasiswa yang memiliki keterampilan berpikir kreatif cenderung terjadi kelancaran dalam membuat berbagai ide/gagasan, Kelenturan dalam mengemukakan pendekatan, Menghasilkan sesuatu yang baru, Merinci atau membangun sesuatu dari ide-ide lainnya. Berdasarkan hal tersebut peneliti melaksanakan pengembangan media ajar pada mata kuliah Asia Timur berbasis Augmented Reality dalam meningkatkan keterampilan berpikir kreatif. Adapun tujuan dari penelitian ini yaitu untuk mengetahui langkah-langkah implementasi bahan ajar berbasis Augmented Reality dan mengetahui peningkatan keterampilan berfikir mahasiswa. Metode penelitian yang digunakan dalam penelitian ini adalah metode penelitian research and development (penelitian dan pengembangan) model Lee and Owens. Populasi yang digunakan dalam penelitian ini adalah mahasiswa Jurusan Pendidikan Sejarah Universitas Negeri Medan yang mengambil mata kuliah Sejarah Asia Timur. Sample yang diambil pada saat uji terbatas yaitu kelas A Reguler 2019, sedangkan pada saat uji coba luas ialah kelas B Reguler 2019 dengan menggunakan Quasi Experimental Design bentuk Nonequivalent Control Group Design. Berdasarkan hasil pengolahan data, dapat disimpulkan bahwa pengembangan bahan ajar berbasis Augmented Reality lebih efektif digunakan dalam mata kuliah Sejarah Asia Timur dalam meningkatkan keterampilan berfikir kreatif mahasiswa dibandingkan tidak menggunakan bahan ajar berbasis augmented reality.
\end{abstract}

Kata kunci: Asia Timur, Augmented Reality, Berfikir kreatif. 


\section{PENDAHULUAN}

Ditengah masa pandemi Covid-19 yang sudah ini, proses perkuliahan menjadi berubah, dilarangnya berkumpul dan bertatap muka sangat memberi dampak terhadap suasana pembelajaran di kampus. Sistem pembejaran daring diwajibkan oleh pemerintah untuk mengatasi penyebaran virus yang semaki masif, Supaya proses perkuiahan tidak terhenti selama masa pandemi ini. Tenaga pengajar dalam ha ini Dosen harus beradaptasi dengan pemakaian tekhnologi dalam menunjang pembelajaran online dalam sarana penting keberlangsungan proses belajar jarak jauh. Memang akan banyak kendala dikarenakan interaksi langsung yang biasa dilakukan dirubah melalui virtual. Kemampuan dosen dalam berkreatifitas untuk memodifikasi bahan ajar sehingga materi dapat tersampaikan dengan baik.

Tekhnologi Augmented reality ialah suatu media dimana informasi digital ditambahkan ke dunia fisik semacam penghadiran realitas virtual, Penjembatanaan interaksi manusia dengan komputer (Alan, 2013). Terlespas itu Augmented reality juga mengijinkan pengguna untuk meihat lingkungan nyata yang ditumpangi oleh objek virtual sehingga objek virtual akan melekat dan menutupi lingkungan nyata dan pengguna akan melihat keduanya dalam wilayah yang sama (Azuma, 1997). Adapun menurut Carmigniani dan furth dalam berinteraksi Augmented Reality dapat dimodifikasi dan diubah oleh pengguna sesuai selera berdasarkan objek dari dunia fisik. Karena biasanya keterbatasan bahan fisik untuk dapat memberikan informasi lebih lanjut sehingga dapat dipaparkan melalui penggunaan Augmented Reality.

Potensi Augmented Reality dalam pengembangan pembelajaran di masa depan apa lagi dalam masa pandemi ini sangatlah besar. Dengan kemampuan menyatukan objek virtual dan realitas secara bersama-sama akan melahirkan kemungkinan baru dalam meningkatkan mutu pembelajaran. Augmented Reality muncul di berbagai bidang pendidikan di berbagai kawasan seperti sejarah, matematika, dan lain-lain (Nincarean, 2013). Awalnya augmented digunakan dalam menghadirkan lingkungan kerja baru dalam wilayah kerja seorang arsitek. Penggunan aplikasi tersebut sangat membantu para arsitek dalam mensimulasi 
rancang bangun dibanding menggambar di media kertas (Ignacio, 2012). Simulasi bangunan yang dapat ditenggarai melalui augmented reality cocok digunakan dalam ilmu sejarah. penghadiran situs-situs ataupaun bangunan peninggalan sejarah akan menjadi hal menarik apalagi simulasi tersebut terlihat di perangkat Android mahasiswa. Suasana perkuliahan sejarah akan semakin hidup dan menyenangkan tidak lagi menjemukan disebabkan biasanya sejarah hanya berkutat pada penghafalan tanggal-tanggal peristiwa bersejarah.

Sejarah Asia timur merupakan salah satu mata kuliah yang terdapat di dalam kurikulum Prodi Pendidikan Sejarah Universitas Negeri Medan, dimana didalamnya akan mempelajari tentang negara-negara maju seperti Cina, Jepang, Korea. Negara-negara tersebut kaya akan situs-situs sejarah bahkan merupakan warisan dunia. Kawasan Asia Timur merupakan percontohan dalam bidang tekhnologi dan majunya sistem pendidikan. Ditambah lagi dengan intensnya generasi muda bersinggungan dengan budaya Kpop (Korea) dan Anime (Jepang). Perhatian generasi muda dalam hal ini mahasiswa pendidikan sejarah harus dapat difasilitasi dengan baik. Sehingga hobi mereka bisa tersalurkan dalam proses susasana perkuliahan. Link and match tersebut dapat menjadi kunci peningkatan nilai akademik mereka terhadap mata kuliah sejarah asia timur. Tidak bisa dipungkiri Anggapan umum mahasiswa untuk sekedar lulus dalam materi ini menjadi pandangan umum. Tetapi disisi lain dosen juga kurang menggali sumber informatif terbaru tentang materi sejarah asia timur, penggunaan media konvensial sekedar power point juga mendukung anggapan umum tadi. Penggunaan bahan ajar sebagai media perantara penyampai pesan memiliki peranan yang sangat penting agar mengurangi kegagalan selama proses interaktif berlangsung.

Perkuliahan Sejarah Asia Timur akan menjadi menarik bila dikolaborasikan dengan aplikasi Augmented Reality. Peninggalan bersejarah di kawasan Asia Timur yang berlimpah akan lebih mudah dieksplorasi oleh mahasiswa. Penghadiran objek bangunan-bangunan bersejarah, akan memicu kreativitas berpikir mereka. Penggunaan Augmented Reality memungkinkan siswa dapat berinteraksi dengan konten digital yang dapat meningkatkan imajinasi, kreativitas dan belajar (Lee \& Owens (2004). Kreativitas berpikir amat 
penting ditingkatkan di masa pandemi ini, sehingga pembelajaran jarak jauh tidak menjadi hambatan dan alasan untuk tidak memahami perkuliahan. Karena keterampilan berpikir kreatif tersebut nantinya sangat berguna bagi mahasiswa untuk modal dalam berkompetisi dalam dunia kerja dan kehidupan bermasyarakakat. Khususnya mahasiswa jurusan pendidikan sejarah, yang dapat menjadi pionir dalam inovasi gaya pembelajaran melalui pengembangan bahan ajar berbasis Augmented Reality. Penelitian ini bertujuan untuk mengetahui desain pengembangan bahan ajar berbasis agumented reality dalam meningkatkan ketereampilan berfikir kreatif.

\section{METODE PENELITIAN}

Model penelitian dalam penelitian ini menggunakan model Lee \& Owens (8) pemilihan model ini dalam pengembangan terhadap Bahan Ajar berbasis Augmented Reality disebabkan model ini sangat lengkap dan rinci untuk memandu pengembangan media pembelajaran. Model Lee \& Owens terdiri atas 4 tahapan yaitu assesment/analysis, design, development and implementation dan evaluation. Pada tahapan analisis dan penilaian kebutuhan untuk menentukan kesenjangan antara keadaan yang ada dengan harapan yang akan dicapai. Bagian selanjutnya ialah front-end analys. Dalam front-end analysis dijabarkan tentang audience analysis, technology analysis, task analysis, critical-incident analysis, situasional analysis, objective analysis, issue analysis, media analysis, extant data analisis.

\section{DISKUSI DAN PEMBAHASAN}

\section{A. Pengembangan Bahan Ajar Berbasis Augmented Reality}

Langkah Awal dalam pengembangan bahan ajar berbasis augmented reality ialah mendesain bahan ajar modul buku teks berisi materi perkuliahan sejarah asia timur. Kemudian di setiap lampiran gambarnya akan dibuatkan barcode yang nantinya jika di scan oleh perangkat android pengguna akan menampilkan gambar augmented reality dari materi tersebut. Lalu peneliti akan meminta validasi dari ahli dan direvisi desainnya baik isi materi maupun tampilan 
gambar (display). Setelah selesai direvisi bahan ajar berbasis augmented reality akan di eksperimenkan kepada kelas terbatas.

Peneliti akan mempublish materi bahan ajar pada media daring perkuliahan sejarah asia timur via Zoom. Selanjutnya akan menyuruh mahasiswa untuk mengunduh bahan ajar yang dipublish di Zoom tadi. Pada saat observasi awal peneliti memberikan pertanyaan dan wawancara terbuka kepada sepuluh orang mahasiswa pendidikan sejarah kelas A Reguler dalam dimintai pendapatnya mengenai keterbacaan isi, bahasa, gambar, penyajian, desain, kegrafisan bentuk dan ukuran huruf yang digunakan dalam bahan ajar berbasis augmented reality. Hasil penelitian yang dilakukan terhadap mahasiswa tersebut pada saat ujicoba terbatas mereka mengataan bahwa keterbacaan isi yang dipakai disusun secara sistematis dan jelas.

\section{B. Langkah-langkah Implementasi Pengembangan Bahan Ajar Berbasis Augmented Reality}

Penelitian ini menggunakan model Lee \& Owens (2004) dalam membuat bahan ajar berbasis Augmented Reality berupa gambar dan informasi mengenai sejarah di Asia Timur. Berikut akan dijelaskan tahapan-tahapan yang digunakan melalui model penggembangan yang dipiilih tersebut.

Pada tahapan pengembangan akan analisis kebutuhan dosen melakukan penelitian pendahuluan untuk mengetahui keadaan yang sedang terjadi di lapangan dalam hal ini mahasiswa pendidikan sejarah stambuk 2019. Penggunaan angket, observasi dilapangan maupun studi pustaka menjadi pengumpul data untuk memahami kebutuhan seperti apa yang berguna bagi pegembangan Augmented Reality.

Hasil dari observasi awal menunjukkan bahwa mahasiswa masih kesulitan untuk memahami materi tentang perkuliahan Asia Timur. Mereka hanya dapat menjelaskan sebagian kecil sejarah mengenai wilayah Asia Timur. Padahal sejarah di Asia Timur amat kaya dan sangat populer di Dunia seperti Tembok besar Cina, Samurai Jepang misalnya. Minimnya ketertarikan dan pengetahuan mereka akan sejarah di Asia Timur dikarenakan kurangnya waktu (SKS) untuk 
membahas detail dan spesifik mengenai Sejarah Asia Timur dan kurangnya pengembangan baik dari model ataupun media yang di gunakan selama proses perkuliahan di kelas.

Penggunaan angket juga dilakukan untuk menganalisis masalah dan kebutuhan akan penggunaan media seperti apa yang dibutuhkan oleh mahasiswa dalam memfasilitasi pembelajaran dengan mereka. Jadi angket akan digunakan dalam bentuk 20 soal yang mencangkup tentang perkembangan kreativitas yang lakukan oleh mahasiswa dalam pembelajaran berbasis augmented reality.

Berlandaskan dari hasil observas dan angket tersebut tersebut dapat disimpulkan jika mata kuliah Asia Timur membutuhkan penyampaian materi melalui Media yang dapat diakses kapanpun dan dimanapun. Dalam hal ini Android (Smart Phone) mereka dapat dimanfaatkan sebagai media pembelajaran. Sehingga mahasiswa dapat mengulang lagi kajian materi yang sudah dibahas di pertemuan tersebut kapan saja ketika mahasiswa kurang memahami perkuliahan yang telah berlangsung.

Sementara itu, kegiatan studi pustaka dilakukan di perpustakaan universitas negeri medan maupun koleksi dari prodi pendidikan sejarah dalam acuan pengembangan materi apa yang dapat dikembangkan serta informasi sejarah mutakhir mengenai sejarah Asia Timur. Yang nantinya akan dikemas menjadi sebuah buku untuk menambah khazanah sumber belajar di kelas.

\section{Peningkatan Keterampilan berfikir}

Dalam mengetahui serta mengevaluasi bahan ajar berbasis augmented reality dalam meningkatkan keterampilan berfikir kreatif dapat dilihat dari hasil angket yang disebarkan di kelas uji eksperimen. Dari hasil angket terhadap keterampilan berfikir kreatif pada saat ujicoba terbatas, sebelum menggunakan bahan ajar augmented reality pretest awal keterampilan berfikir kreatif sebesar 65,8\% lalu mengalami kenaikan setelah adanya penggunaan bahan ajar augmented reality menjadi $86,4 \%$. Sedangkan pada ujicoba luas, hasil pretest awal keterampilan berifikir kreatif mahasiswa di kelas eksperimen yaitu 73,3\% sedangkan hasil pretest di kelas kontrol sebesar 53,7\%. Hasil tersebut diperoleh 
dari skor rata-rata angket yang terdiri dari 30 responden. Setelah peneliti menggunakan bahan ajar berbasis augmented reality terjadi peningkatan pada kelas eksperimen sebesar 92,5\% sedangkan di kelas kontrol yaitu 76,7\%. Artinya keterampilan berfikir kreatif di kelas eksperimen terjadi peningkatan signifikasi dibandingkan kelas kontrol yang tidak menggunakan bahan ajar berbasis augmented reality.

Analisis data pengembangan bahan ajar augmented reality terhadap keterampilan berfikir kreatif mahasiswa berdasarkan hasil penelitian diatas dimana kelas eksperimen terjadi peningkatan labih besar dibandingkan kelas kontrol. Tetapi sebelum itu, peneliti telah melakukan analisis data pretest awal dan postest akhir di kelas eksperimen mengenai keterampilan berfikir kreatif sebelum dan sesudah menggunakan pengembangan bahan ajar berbasis augmented reality. Pengujian dilakukan untuk menguji rata-rata kelas. Pengujian ini menggunakan uji-t dengan asumsi data berdistribusi normal dan homogenitas varian. Berdasarkan pengolahan data terdapat 30 mahasiswa pada kelas eksperimen yang memiliki nilai rata-rata pretest sebesar 78,4 sedangkan pada kelas kontrol yaitu 53,7 lalu nilai rata-rata postest pada kelas eksperimen sebesar 94,2 dan pada kelas kontrol adalah 78,3. Uji normalitas dan homogenitas menggunakan alat bantu SPSS. Data normal menggunakan uji KolmogorovSmirnov sebab sampel yang dipakai peneliti lebih dari $50(>50)$, suatu data disebut normal dalam uji ini apabila nilai signifikasi atau probalitas >0,05 maka distribusi normal. Hasilnya dimana signifikansi kelas eksperimen sebesar 0,200 melebihi 0,05 dan pada kelas kontrol sebesar 0,200 melebihi 0,05. Sedangkan pada nilai postest kelas eskperimen memiliki sig 0,200 melebihi nilai 0,05 lalu pada kelas kontrolnya sebesar 0,20 melebihi 0,05. Dengan demikian dapat diambil kesimpulan bahwa data pretes dan postest pada kelas eskperimen maupun kontrol berdistribusi normal.

Pada uji homogenitas kelas ekspermen dan kontrol yaitu 0,326 lebih besar dari 0,05. Pada data homogenitas populasi memiliki variansi yang sama, maka dari itu digunakan niali $\mathrm{t}$ dan sig pada baris Equal Varinces Assumed. Berdasarkan hasil perhitungan tersebut menunjukkan t hitung sebesar 12,628 
dengan menggunakan tabel derajat kebebasan $(\mathrm{df})=52$, dan tingkat signifikasi 95\% atau $\alpha=5 \%$ diperoleh ttabel sebesar 1,756 dengan demikian dapat disimpulkan bahwa t hitung $>$ t table $(12,628>1,756)$ dan tampak level sig $0,000<$ 0,05 maka dsimpulkan H0 diterima. Sedangkan untuk perhitungan uji t data postest menunjukkan nilai 13,2653 dengan menggunakan tabel pada derajat kebebasan $(d f)=52$ dan tingkat signifikansi sebesar 95\% atau $\alpha=5 \%(0,005)$ diperoleh tabel sebesar 1,745. Dengan demikian bahwa $t$ hitung>t tabel $(13,2653>1,745)$ dan bilah dilihat dari lebel signifikansi tampak bahwa sig 0,000 $<0,05$ maka dapat disimpulkan H0 diterima. Setelah mengetahui hasil angket untuk keterampilan berpikir kreatif di kelas eksperimen maupun kelas kontrol, selanjutnya peneliti melakukan uji gain. Dimana data uji gain kelas eksperimen dengan rata-rata nilai pretest adalah 76,8 dan rata-rata nilai posttest adalah 92,7 ini menunjukkan adanya selisih peningkatan sebesar 15,9 dan mempunyai angka Gain sebesar 0,75. Angka Gain ini termasuk kriteria tinggi. Sedangkan uji Gain kelas kontrol dengan nilai pretest sebesar 53,7 dan rata-rata nilai posttest adalah 76,5 ini menunjukkan adanya selisih peningkatan 22.8 dan mempunya angka Gain sebesar 0,62. Angka Gain ini termasuk kriteria sedang.

Rancangan desain awal penelitian ini berfokus kepada profil bahan ajar berbasis augmented reality yang menjadi daya tarik bahan ajar ini seperti bagian sampul depan, isi, bagan atau peta konsep. Cover didesain dengan mencantumkan gambar augmented reality situs sejararah asia timur agar mahasiswa memiliki keinginan tinggi untuk membaca isi dari bahan ajar didesain dengan mengutamakan karakteristik bahan ajar yang bersahabat dengan penggunanya. Setiap instruksi atau paparan materi dibuat dengan menggunakan kalimat yang sederhana dan isi materi yang tidak terlalu banyak tulisan hanya pokok bahasan secara garis besar. Isi barcode harus terkait dengan meteri yang sedang dibahas, lalu animasi tampilan dibuat semenarik mungkin dan senyata mungkin sesuai dengan situs atau peninggalan sejarah dengan pewarnaan yang jelas dan enak dipandang mata.

Peneliti melakukan wawancara yang langsung didokumentasikan dalam bentuk video dengan 8 mahasiswa di kelas eksperimen ujicoba terakhir 
dilaksanakan dan mahasiswa mengatakan adanya bahan ajar berbasis augmented reality ini sangat membantu sekali. Kendala pembelajaran jarak jauh terkait minim materi dapat teratasi dengan adanya bahan ajar berbasis augmented realiti yang simpel dan dapat langsung digunakan dalam perangkat smartphone mereka.

Perkuliahan dapat dilakukan dirumah tanpa ngumpul-ngumpul di kelas untuk menghindari cluster covid 19. 4 mahasiswa lainnya menjelaskan bahwa melalui penggunaan bahan ajar berbasis augmented reality ini pembahasan materi menjadi lebih jelas dan tidak bertele-tele. 3 mahasiswa lainnya mengatakan ini merupakan pengalaman pertama mereka terkait augmented reality, dan sangat membantu mereka yang lebih memahami sebuah materi jika terdapat gambar dibandingkan sekedar teks saja.

Peningkatan keterampilan berfikir kreatif mencapai 0,75 pada kelas eksperimen dan kelas kontrol sebesar 0,62, maka dari hasil tersebut dijelaskan bahwa interpretasi nilai gain kelas eksperimen dibandingkan kelas kontrol. Hal ini dapat terlihat ketika peneliti akan melakukan postest dimana kelas eksperimen memiliki keterampilan berfikir kreatif lebih tinggi dibandingkan kelas kontrol. Pengembangan bahan ajar berbasis augmented rality juga disesuaikan dengan kebutuhan mahasiswa sehingga keterampilan berifikir kreatif terjadi penigkatan dan mahasiswa dapat menciptakan hal-hal baru dan unik sehingga perkuliahan menjadi lebih bermakna.

\section{PENUTUP}

Melalui hasil pengamatan, analisis, dan pembahasan yang telah dipaparkan maka peniliti mengambil kesimpulan yaitu 1. Pengembangan bahan ajar berbasis augmented reality diawali dengan mengembangkan konten yang meliputi: a. Penentuan materi yang dibuat disesuaikan dengan kebutuhan mahasiswa dalam hal ini mata kuliah sejarah asia timur. b. Desain bahan ajar augmented reality dibuatkan cover ilustrasi gambar augmented reality terkait materi. c. Bahasa dan gambar bahan ajar menggunakan bahasa yang mudah dipahami dan komunikatif sehingga meminimalisir kesalahpahaman. d. penyajian materi bahan ajar augmented reality dapat menimbulkan susasana antusias dalam membaca. e. 
Pengembangan bahan ajar dapat diaplikasikan ke smartphone dengan file yang ringan sehingga mengurangi keerorran dalam pengoperasiannya. f. Bahan ajar berbasis augmented reality ini telah diuopload di dalam zoom sehingga mahasiswa dapat mengunduh file dengan mudah. Hasil validasi ahli materi juga menunjukkan bahwa hasil validasi ahli materi untuk komponen isi mendapat skor rata-rata 4,7 dan 4,66 untuk komponen bahasa. Total rata-rata skor untuk kedua komponen mencapai 4,69 dengan kategori "Sangat Baik". Berdasarkan hasil ini, Bahan Ajar Sejarah Asia Timur berbasis Augmented Reality layak diuji coba tanpa harus melakukan revisi.

Adapun 2. Yaitu langkah-langkah implementasi penggunaan bahan ajar augmented reality dapat dilihat dari skor interpretasi dari obervasi pada pertemuan satu yaitu 90\% kemudian mengalami kenaikan kedua menjadi 100\%. 3. Peningkatan keterampilan berfikir kreatif . menggunakan bahan ajar berbasis augmented reality terjadi peningkatan pada kelas eksperimen sebesar 92,5\% sedangkan di kelas kontrol yaitu 76,7\% lalu hasil pengitinhan t hitung dimana $t$ hitung $>\mathrm{t}$ tabel $(13,2653>1,745)$. Artinya terdapat perbedaaan keterampilan berfikir kreatif yang signifikan antara kelas eksperimen dengan kelas kontrol. Peningkatan keterampilan berfikir kreatif ini sudah diuji dengan nilai gain dimana kriteria kelas eksperimen sebesar 0,75 pada kelas eksperimen dan kelas kontrol sebesar 0,62. Jadi penggunaan bahan ajar augmented reality pada mahasiswa pendidikan sejarah dalam mata kuliah sejarah asia timur sangat layak dan dapat meningkatkan keterampilan berfikir kreatif. Mengembangkan lebih lanjut Bahan Ajar Sejarah Asia Timur berbasis Augmented Reality sebagai media pembelajaran sejarah. Hal ini penting untuk memperkaya media pembelajaran sejarah yang inovatif dengan cakupan bahasan yang luas untuk mendukung proses pembelajaran sejarah di Jurusan Pendidikan Sejarah Universitas Negeri Medan 


\section{DAFTAR REFERENSI}

Akbar, S, (2013).Intstrumen Perangkat Pembelajaran . Remaja Rosdakarya Offset, Bandung..

Alan B. Craig, (2013). Understanding Augmented Reality: Concept and Aplications. Morgan Kaufmann, San Fransisco.

Azuma Ronald T, (1997). A Survey of Augmented Reality. Presence: Teleoperators and Virtual Environments Vol. 6 No. 4 Hal: 355-385.

Carmigniani dan Furth. Technology, System, and Aplication Augmented Reality. Tools and Aplication Multimedia. Vol. 51 No. 1 Hal: 341-377

Ignacio, Redondo, (2012). The Behavorial Effects of Negative Product Placements in Movies. Vol. 20 Np. 8

Lee, W. \& Owens, D,L., (2004). Multimedia Based Instructional Design , Second Edition. John Willey \& Sonc, Inc, United States Of America

Nincarean, Danakom et al, (2013). Mobile Augmented Reality: the potensial for Education. Procedia - Social and Behavioral Sciences 103 (657-664). Universitas Teknologi Malaysia.

Persefoni and Tsinakos, (2015). Use of Augmented Reality in terms of creativity in School Learning. ICEC'15, Norway.

Wang, X, (2009). Augmented Reality in Archithecture and Design: Potentials and Challanges for Aplication. International Journal of Architectural Computing. Issue 2 Vol. 7 